\title{
Transport zwierząt egzotycznych w UE a multicentryczność systemów prawnych na przykładzie regulacji odnoszących się do transportu tygrysów z Włoch przez terytorium Rzeczypospolitej Polskiej w 2019 r.
}

\author{
Transportation of exotic animals and multicentric legal systems \\ on the example of regulations governing the transportation of tigers \\ from Italy through the territory of Poland in 2019 \\ Перевозка экзотических животных в ЕС а мультицентричность правовых \\ систем на примере правил, касающихся перевозки тигров \\ из Италии через территорию Республики Польша в 2019 году \\ MAŁGORZATA LUBELSKA-SAZANÓW \\ Dr, Uniwersytet Śląski \\ e-mail: malgorzata.lubelska-sazanow@us.edu.pl, https://orcid.org/0000-0002-0381-7142
}

\begin{abstract}
Streszczenie: Głównym założeniem publikacji jest ocena norm prawnych dotyczących przewozu zwierząt egzotycznych obowiązujących na terenie Unii Europejskiej, ze szczególnym uwzględnieniem ich obowiązywania i przestrzegania w krajach, w których doszło do ich naruszenia lub nieskutecznego zastosowania w przypadku transportu tygrysów z Włoch przez terytorium Rzeczypospolitej Polskiej w 2019 r. Na podstawie analizy zależności pomiędzy nieprawidłowościami w stosowaniu regulacji prawnych dotyczących przewozu zwierząt egzotycznych w Europie, a wystąpieniem sytuacji faktycznej, w której doszło do śmierci jednego z tygrysów i zagrożenia życia pozostałych osobników, możliwe jest także znalezienie odpowiedzi na pytanie, czy w przedstawianym stanie prawnym występuje tzw. luka prawna, jak również zaproponowanie subiektywnych rozwiązań prawnych mających na celu uniknięcie podobnych sytuacji w przyszłości. Zawarte w tekście rozważania dokonywane są na podstawie rozporządzeń i dyrektyw UE oraz przepisów krajowych (przy czym w odniesieniu do stosowania przepisów prawnych UE - zachodzą także odniesienia do ich stosowania przez włoskie organy prawa, jako kraju w którym rozpoczął się transport tygrysów). W zakończeniu przedstawione zostały wnioski, mające na celu zapewnić większą ochronę zwierzętom egzotycznym w czasie ich transportu (przede wszystkim transgranicznego). Autorka wykazuje ostatecznie, że w opisywanym przypadku nie występuje luka prawna, a doszło jedynie do błędnej interpretacji, a następnie stosowania prawa UE przez organy państwowe Włoch i Polski, wskazując podstawowe zagrożenia dobrostanu dzikich zwierząt podczas transportu przez kraje UE. Po pierwsze: brak jest odgórnego systemu kontroli na poziomie UE; po drugie: uwidocznione zostały wady funkcjonowania systemu TRACES, po trzecie: dużą trudność sprawia wskazanie norm prawnych dotyczących zwierząt egzotycznych na poziomie ponadnarodowym.
\end{abstract}

Słowa kluczowe: multicentryczność systemów prawnych, zasada pierwszeństwa prawa UE, zwierzęta egzotyczne, transport zwierząt zagrożonych, prawo UE, międzynarodowe prawo publiczne, prawo publiczne, prawo weterynaryjne, tygrysy

Summary: The main aim of this publication is the evaluation of legal norms governing the transportation of exotic animals in the EU, specifically in reference to its enforcement and effectiveness in the EU countries mostly involved in the transportation of tigers in 2019, to which this text refers. The analysis of the presented legal and 
factual situation allows one to determine whether there is a legal loophole in the described case, as well as find legal solutions how to avoid such situations in the future. The considerations contained in the publication are based on EU regulations and directives as well as national regulations (with regard to the application of EU legislation by different EU Member countries, since there are also references to its application by Italian law authorities to the country in which the transport of tigers began). At the end follows a presentation of conclusions on how to ensure greater protection of exotic animals during their transportation (mainly transboundary). The author shows that in the described case is no legal loophole, but only a misinterpretation and then application of EU law by the Italian and Polish state authorities, pointing to the basic threats to the welfare of wild animals during transport through EU countries. Firstly, there is no top-down control system at the EU level; secondly, the shortcomings of the TRACES system were highlighted; thirdly, it is very difficult to identify legal norms at the supranational level regarding exotic animals.

Key words: multicentric legal systems, primacy of EU law, exotic animals, transportation of endangered species, EU law, public international law, public law, veterinary law, tigers

Резюме: В статье представлена оценка правовых норм по перевозке экзотических животных, действующих в Европейском Союзе, с особым акцентом на их действительность и соблюдение в странах, где они были нарушены или неэффективно применены в описанном случае. На основе анализа взаимосвязи между нарушениями в применении правовых норм по перевозке экзотических животных в Европу и возникновением фактической ситуации, в которой один из тигров погиб, а жизнь других оказалась под угрозой, можно сделать вывод о том, существует ли так называемый пробел в праве в представленном правовом статусе, а также предложить субъективные правовые решения, предотвращающие подобные ситуации в будущем. Приведенные в тексте соображения основаны на положениях и директиBax EC, а также на национальном законодательстве, причем в отношении применения законов ЕС также делается ссылка на их применение законодательными органами Италии как страны, где началась перевозка тигров. В заключении даются предложения по усилению защиты экзотических животных при их транспортировке (в первую очередь трансграничной). Автор показывает, что в описанном случае нет никакого пробела в праве. Имело место лишь неверное толкование и неправильное применение законодательства ЕС государственными органами Италии и Польши. Указывается также на основные угрозы благополучию диких животных во время транспортировки через страны ЕС. Во-первых, на уровне ЕС не существует система внешнего контроля, во-вторых, отмечаются недостатки в функционировании системы TRACES; в-третьих, очень сложно определить правовые стандарты на наднациональном уровне в отношении экзотических животных.

Ключевые слова: многоцентричность правовых систем, принцип верховенства права ЕС, экзотические животные, перевозка исчезающих видов животных, право ЕС, международное публичное право, публичное право, ветеринарное законодательство, тигры

\section{Wstęp}

W czasie składania niniejszego artykułu do druku mija dokładnie rok od zaistnienia sytuacji narażenia zdrowia i życia dziesięciu tygrysów transportowanych z Włoch do Dagestanu (Federacja Rosyjska) w obszernie dyskutowanej medialnie sprawie tzw. „tygrysów z białoruskiej granicy”. Na skutek zawrócenia transportu przez białoruską straż graniczną zwierzęta przebywały kilka dni na polsko-białoruskim przejściu granicznym bez możliwości ich rozładowania, a jedno z nich padło już w dniu zatrzymania transportu. Wyniki przeprowadzonej u padniętego osobnika sekcji zwłok wykazały, że tygrysy nie były karmione pożywieniem odpo- 
wiednio dobranym dla tego gatunku zwierząt $\mathrm{w}$ trakcie transportu ${ }^{1}$. Dodatkowo podczas postoju brak było możliwości nakarmienia i napojenia osobników znajdujących się w głębi naczepy ciężarówki² jako iż drewniane klatki z agresywnymi osobnikami blokowały dostęp do pozostałych zwierząt. Opisywany w niniejszym artykule przypadek transportu tygrysów (w dalszej części artykułu skrótowo określany: transport tygrysów) wywołał w Polsce i pozostałych krajach członkowskich Unii Europejskiej (dalej: UE) dyskusję na temat prawidłowości stosowania regulacji prawnych dotyczących transportu zwierząt egzotycznych w prawodawstwie UE oraz systemach prawnych krajów członkowskich.

Głównym założeniem publikacji jest ocena norm prawnych dotyczących przewozu zwierząt egzotycznych obowiązujących na terenie UE oraz ich stosowania na przykładzie krajów, w których doszło do ich potencjalnego naruszenia w określonej sytuacji faktycznej, jakim był przedmiotowy transport tygrysów (z zastosowaniem metody formalno-dogmatycznej i wykorzystaniem materiałów empirycznych, np. artykułów prasowych, oświadczeń organów administracji) ${ }^{3}$. Na podstawie analizy zależności pomiędzy nieprawidłowościami w stosowaniu regulacji prawnych dotyczących przewozu zwierząt egzotycznych w Europie a wystąpieniem sytuacji faktycznej, w której doszło do śmierci jednego z tygrysów i zagrożenia życia pozostałych osobników, możliwe jest także znalezienie odpowiedzi na pytanie, czy w przedstawianym stanie prawnym występuje tzw. luka prawna, jak również zaproponowanie subiektywnych rozwiązań prawnych mających na celu uniknięcie podobnych sytuacji w przyszłości. Ma to istotne znaczenie, gdyż transport zwierząt uważany jest przez niektórych przedstawicieli doktryny za najtrudniejsze zagadnienie dotyczące ochrony zwierząt ${ }^{4}$, a opisywany przypadek transportu tygrysów

1 Portal internetowy TVN24 (Autor: js//now,FC/gp), Udało nam się uratować dziewięć istnień tygrysich. Jeden jest $w$ ciężkim stanie, https://tvn24.pl/polska/tygrysy-z-granicy-z-bialorusia-trafily-do-zoo-w-poznaniu-i-czluchowie-ra981836-2307337 [dostęp: 10.02.2020 r.].

2 Zgodnie $\mathrm{z}$ informacją pochodzącą od Głównego Inspektoratu Weterynarii, podaną na podstawie dokumentu weterynaryjnego INTRA (świadectwo zdrowia przewożonych zwierząt wygenerowane przez jednostkę weterynaryjną we Włoszech), zwierzęta zostały wysłane z Włoch 22 października 2019 r., a 26 października dotarły na przejście graniczne w Polsce w Koroszczynie. Białoruskie służby graniczne odmówiły wjazdu transportu z tygrysami na terytorium Białorusi ze względu na brak wymaganych w tym kraju urzędowych certyfikatów weterynaryjnych wystawionych przez włoskie służby weterynaryjne oraz brak aktualnych wiz kierowców przewożących zwierzęta.

3 Por. rodzaje metod badawczych, np. Z. Ziembiński, Metodologiczne zagadanienia prawoznawstwa, Warszawa 1974, s. 80; T. Pietrzykowski, Naturalizm i granice nauk prawnych. Esej z metodologii prawoznawstwa, Warszawa 2017, s. 46-68.

4 M. Dendera-Gruszka, D. Masłowski, E. Kulińska, D. Maras, Uwarunkowania prawne dotyczace pojazdów wykorzystywanych do przewozu zwierzą, w: Innowacje w zarzadzaniu i inżynierii produkcji, t. 1, red. R. Konsala, Opole 2018, s. 712. 
potwierdza jedynie, że często dochodzi do nadużyć w tym zakresie. Zawarte w nim rozważania dokonywane są na podstawie rozporządzeń i dyrektyw UE oraz polskich przepisów krajowych jako państwa, w którym doszło do zatrzymania transportu tygrysów (przy czym w odniesieniu do stosowania przepisów prawnych UE zachodzą także nawiązania do ich stosowania przez włoskie organy prawa jako kraju, w którym rozpoczął się transport tygrysów) ${ }^{5}$. W zakończeniu przedstawione zostaną wnioski mające na celu zapewnić większą ochronę zwierzętom egzotycznym w czasie ich transportu (przede wszystkim transgranicznego).

\section{Multicentryczność krajowych systemów prawnych wewnątrz UE a stosowanie regulacji prawnych dotyczących przewozu zwierząt egzotycznych}

Polski system prawny (zgodnie zresztą z obowiązującą tendencją współczesnych systemów prawa $)^{6}$ jest multicentryczny ${ }^{7}$, co oznacza m.in., że znajdują się w nim wzajemnie oddziałujące na siebie centra decyzyjne ${ }^{8}$. W kontekście analizowanej problematyki zjawisko to jest istotne szczególnie w odniesieniu do zewnętrznego wpływu na krajowy porządek prawny. Jednym z jego przejawów jest fakt, że ośrodki zewnętrzne (w tej sytuacji organy UE) mogą w wiążący sposób stanowić prawo obowiązujące na terenie Rzeczpospolitej Polskiej (w sposób bezpośredni lub pośredni), a także podejmować decyzje o skutecznym jego stosowaniu i interpretacji ${ }^{9}$. Przy stosowaniu i interpretacji norm prawnych kluczowa jest zatem świadomość interpretatora, że ośrodki zewnętrzne mogą w wiążący sposób podejmować decyzje o stosowanym prawie na terenie Rzeczpospolitej Polskiej (np. poprzez

5 Należy także zwrócić uwagę na działania Rady Europy, która - jako pierwsza - wykazała zainteresowanie transportem zwierząt, wydając w 1968 r. europejską Konwencję o ochronie zwierząt podczas przewozów międzynarodowych. Kwestie te zostały jednak pominięte w opracowaniu ze względu na brak realnego wpływu konwencji Rady Europy na opisywany przypadek i konieczność ograniczenia objętościowego tekstu.

6 Zob. A. Kustra, Polemika. Wokót multicentryczności systemu prawa, Państwo i Prawo 2006, z. 6, s. 85.

7 Tak właśnie A. Kalisz, Multicentryczność systemu prawa polskiego a działalność orzecznicza Europejskiego Trybunału Sprawiedliwości i Europejskiego Trybunału Praw Człowieka, Ruch Prawniczy, Ekonomiczny i Socjologiczny 2007, z. 4, s. 35.

8 Zob. E. Łętowska, Multicentryczność współczesnego systemu prawa i wykładnia jej przyjazna, w: Rozprawy prawnicze. Księga pamiątkowa profesora Maksymiliana Pazdana, red. L. Ogiegło, W. Popiołek, M. Szpunar, Kraków 2002, s. 1127, a także E. Łętowska, Multicentryczność współczesnego systemu prawa i jej konsekwencje, Państwo i Prawo 2005, z. 4, s. 3 i nast.

$9 \quad$ E. Łętowska, Multicentryczność współczesnego systemu prawa i wykładnia jej przyjazna..., s. 1127. 
wydawanie rozporządzeń przed Radę (WE) lub Komisję Europejską) ${ }^{10}$. Rodzime organy państwowe nie zawsze stosują bowiem zasadę pierwszeństwa prawa unijnego ${ }^{11}$. W analizowanym przypadku nie uwzględniono wytycznych dotyczących przewozu zwierząt i obrotu dzikimi zwierzętami oraz zagrożonymi gatunkami znajdujących się w aktach prawnych UE. Dokonano jedynie racjonalizacji działań, powołując się na ich pozorną zgodność z polskim porządkiem prawnym ${ }^{12}$. Fakt zastosowania norm prawnych o krajowej genezie nie oznacza jednak zgodności działań dokonywanych przez dany organ prawa z polskim systemem prawnym (który ze względu na swoją multicentryczność obejmuje także swym zakresem akty prawa UE). Skutek w postaci utraty i narażenia życia i zdrowia tygrysów należy rozpatrywać zatem z szerszej perspektywy, analizując wszystkie jego przyczyny.

\section{Regulacje prawne dotyczące przewozu zwierząt egzotycznych w systemie prawa międzynarodowego, aktów prawnych UE i przepisów prawa polskiego}

W zakresie obowiązujących obecnie norm prawnych regulujących ochronę zwierząt w ogólnym zakresie, zauważalna jest tendencja wydawania aktów prawnych mających na celu ochronę poszczególnych grup zwierzą ${ }^{13}$. Wśród aktów prawnych wydanych przez organy UE są to w szczególności te, które mają na celu

10 Tamże.

11 Zob. w odniesieniu do zjawiska europeizacji prawa administracyjnego L. Klat-Wertelecka, Zasada pierwszeństwa prawa unijnego $w$ działaniu organów administracji publicznej, w: Zasada pierwszeństwa prawa Unii Europejskiej w praktyce działania organów władzy publicznej RP, red. M. Jabłoński, S. Jarosz- Żukowska, Wrocław 2015, s. 185.

12 Zob. podrozdział Prawidłowość stosowania regulacji prawnych systemu prawa UE dotyczacych przewozu zwierząt egzotycznych przez polskie organy państwowe poniżej oraz: Wspólne Oświadczenie Prezesa Krajowej Izby Lekarsko-Weterynaryjnej i Przewodniczącej Ogólnopolskiego Związku Zawodowego Pracowników Inspekcji Weterynaryjnej z dnia 2.12.2019 r., dostępne na stronie Krajowej Izby Lekarsko-Weterynaryjnej, https://www.vetpol.org.pl/images/pismarozne/WSPÓLNE_OŚWIADCZENIE_KILW_OZZPIW.pdf [dostęp: 10.02.2020 r.].

13 Oczywiście, istnieją akty prawne mające na celu zapewnienie podstawowych praw i godności każdemu zwierzęciu bez względu na jego gatunek, jak np. art. 13 Traktatu o Funkcjonowaniu Unii Europejskiej (z uwzględnieniem zmiany wprowadzonych traktatem lizbońskim), Dz. U. z 2004 r. $\mathrm{Nr}$ 90, poz. 864; art. 2; czy też w polskim ustawodawstwie krajowym: art. 1 ustawy z dnia 21 sierpnia 1997 r. o ochronie zwierząt, Dz. U. z 1997 r. Nr 111, poz. 724. Zob. też w odniesieniu do ustawodawstw krajowych innych krajów członkowskich UE: Animal legislations in the world at national level, https://www.globalanimallaw.org/database/national/index.html [dostęp: 10.02.2020 r.]. 
ochronę zwierząt hodowlanych ${ }^{14}$ czy przeznaczonych do uboju ${ }^{15}$. Na szczeblu globalnym obowiązuje już od wielu lat $\mathrm{z}$ dużą efektywnością akt prawny mający na celu ochronę zagrożonych gatunków ${ }^{16}$ - Konwencja o międzynarodowym handlu dzikimi zwierzętami i roślinami gatunków zagrożonych wyginięciem ${ }^{17}$ (którego sygnatariuszem jest również UE, toteż stanowi część porządku prawnego UE).

Żaden z aktów prawnych mających na celu ochronę poszczególnych grup zwierząt nie odnosi się jednak bezpośrednio do ich transportu. W tym celu uchwalone zostały inne akty prawne, regulujące w sposób ogólny kwestie logistyczne dotyczące przewozu wszystkich gatunków zwierząt, jak np. Rozporządzenie Rady (WE) nr 1/2005 z dnia 22 grudnia 2004 r. w sprawie ochrony zwierząt podczas transportu $^{18}$ (dalej: Rozporządzenie Rady (WE) nr 1/2005). Należy natomiast zwrócić uwagę na fakt, że akty prawne mające na celu ochronę zwierząt podczas transportu nie regulują przewozów zwierząt egzotycznych, w tym gatunków zagrożonych

14 Dyrektywa Rady 98/58/WE z dnia 20 lipca 1998 r. dotycząca ochrony zwierząt hodowlanych Dz. Urz. UE L 221 z 8.8.1998, s. 23-27. Por. M.A. Król, Humanitarna ochrona zwierząt, w: Prawa i obowiązki przedsiębiorców $w$ ochronie środowiska. Zarys encyklopedyczny, red. P. Korzeniowski, Warszawa 2010, s. 467, ze względu na opisywaną przez autorkę rozdziału główną przyczynę zainteresowania organów UE zapewnieniem odpowiednich warunków sanitarnych podczas transportu zwierząt, jaką były problemy zdrowotne zwierząt wpływające na handel wewnątrzwspólnotowy bydłem i trzodą chlewną.

15 Rozporządzenie Rady (WE) nr 1099/2009 z dnia 24 września 2009 w sprawie ochrony zwierząt podczas ich uśmiercania, Dz. Urz. UE L 303 z 18.11.2009, s. 1-30.

16 Akt ten obowiązuje także w systemie aktów prawnych UE poprzez odpowiednią implementację do krajowego systemu prawnego, zob. Rozporządzenie Rady (WE) nr 338/97 z dnia 9 grudnia 1996 r. w sprawie ochrony gatunków dzikiej fauny i flory w drodze regulacji handlu nimi, Dz. Urz. UE L 61 z 3.3.1997, s. 1-69 (dalej: Rozporządzenie Rady (WE) nr 338/97). Z dniem 1 czerwca 1997 r. zastąpiło ono wcześniej obowiązujące Rozporządzenie Rady (EWG) nr 3626/82 z dnia 3 grudnia 1982 r. w sprawie stosowania we Wspólnocie Konwencji o międzynarodowym handlu zagrożonymi gatunkami fauny i flory wprowadzające konwencję CITES do prawodawstwa UE, Dz. Urz. WE L 384 z 31.12.1982, s. 1-61 z późn. $z m$.

17 Zwana także konwencją waszyngtońską lub w skrócie CITES. Podstawowe akty prawne implementujące CITES w system prawny aktów UE to: Rozporządzenie Komisji (WE) nr 865/2006 z dnia 4 maja 2006 r. ustanawiające przepisy wykonawcze do rozporządzenia Rady (WE) nr 338/97 w sprawie ochrony gatunków dzikiej fauny i flory w drodze regulacji handlu nimi, Dz. Urz. UE L 166 z 19.6.2006, s. 1-69, zmienione przez Rozporządzenie Komisji (WE) Nr 100/2008.

18 Rozporządzenie Rady (WE) nr 1/2005 z dnia 22 grudnia 2004 r. w sprawie ochrony zwierząt podczas transportu i związanych z tym działań oraz zmieniające dyrektywy 64/432/EWG i 93/119/WE oraz rozporządzenie (WE) nr 1255/97, Dz. Urz. UE L z 5.1.2005, s. 1-44. 
wyginięciem $^{19}$. Powstaje w ten sposób pozorna luka prawna ${ }^{20}$, której genezę przedstawiono w dalszej części tekstu. Ze względu na fakt, że przepisy dotyczące transportu zwierząt oraz te mające na celu ochronę zwierząt dziko żyjących i zagrożonych gatunków nie uzupełniają się wzajemnie w sposób jasny i przejrzysty, prowadzi to często do nieumiejętnej ich interpretacji.

W odniesieniu do prawodawstwa UE aktem prawnym o największym znaczeniu w opisywanym przypadku ${ }^{21}$ jest Dyrektywa Rady 91/628/EWG z dnia 19 listopada 1991 r. w sprawie ochrony zwierząt podczas transportu ${ }^{22}$, w której znajdują się liczne odniesienia do konwencji CITES ${ }^{23}$. Uzupełniające się wzajemnie przepisy konwencji i dyrektywy przedstawiają się jak wykazano poniżej.

Konwencja CITES - mimo iż dotyczy handlu dzikimi zwierzętami, a nie ich przewozu sensu stricto - jest aktem prawnym mającym największe znaczenie przy transporcie zwierząt, takich jak tygrysy (jako gatunek umieszczony w załączniku I do CITES, a zarazem w załączniku A do Rozporządzenia Rady (WE) nr 338/97)24. Zgodnie z postanowieniami Dyrektywy Rady 91/628/EWG tygrysy powinny być przewożone w kontenerach i w warunkach, jakie są właściwe dla danych gatunków. Biorąc pod uwagę, że zwierzęta te objęte są zakresem obowiązywania konwencji

19 Podobna sytuacja zachodzi w odniesieniu do publikacji naukowych na temat transportu; choć wielu polskich autorów odnosi się bowiem do kwestii wymogów stawianych transportowi zwierząt żywych, przypadki transportu zwierząt egzotycznych (w dodatku niebezpiecznych), jak miało to miejsce w sytuacji opisywanej w niniejszym artykule, są na tyle rzadkie, że brak jest do nich odniesień w polskiej literaturze naukowej. Por. np. A. Szczepańska, Wymogi dotyczące środków transportowych przy przewozie zwierzat żywych, Logistyka 2012, nr 3, s. 2159-2164; M. Dendera-Gruszka, D. Masłowski, E. Kulińska, D. Maras, Uwarunkowania prawne dotyczące pojazdów wykorzystywanych do przewozu zwierzat, w: Innowacje w zarzadzaniu i inżynierii produkcji, red. R. Knosala, t. 1, Opole 2018, s. 711-721. Zobacz także inne publikacje w tym temacie, np. K. Hantz, K. Żukowska, A. Grieger, Wymagania stawiane środkom transportu przy przewozie zwierzat żywych, Autobusy 2016, nr 8, s. 236-239; R. Kupczyński, Transport zwierząt - o czym trzeba pamiętać?, agroFakt24, https://www. agrofakt.pl/transport-zwierzat/ [dostęp: 9.03.2021 r.].

20 Obszernie o lukach prawnych: E. Rott-Pietrzyk, w: System Prawa Prywatnego, t. 20A. Prawo prywatne międzynarodowe, red. M. Pazdan, Warszawa 2014, s. 260-273 i cytowane tam piśmiennictwo.

21 Ma to miejsce ze względu na fakt, że podstawowy akt prawny wydany przez organy UE dotyczący transportu zwierząt - Rozporządzenie Rady (WE) nr 1/2005 - mimo iż zawiera nawiązania do gatunków dzikich, nie odnosi się do gatunków egzotycznych (a zatem tygrysów). Tak właśnie Sprawozdanie Komisji dla Parlamentu Europejskiego i Rady w sprawie wpływu rozporządzenia Rady (WE) nr 1/2005 w sprawie ochrony zwierząt podczas transportu, Bruksela, dnia 10.11.2011, $\mathrm{KOM}(2011) 700$ wersja ostateczna.

22 Dyrektywa Rady 91/628/EWG z dnia 19 listopada 1991 r. w sprawie ochrony zwierząt podczas transportu i zmieniającej dyrektywy 90/425/EWG oraz 91/496/EWG (91/628/EWG), Dz. Urz. UE L 340, 11.12.1991, s. 17-27 (dalej: Dyrektywa Rady 91/628/EWG).

23 Zob. L. Krämer, EU Environmental Law, London 2016, s. 213-215 w odniesieniu do relacji między konwencją CITES a aktami prawa UE. 
CITES, ich transport musiał się odbywać zgodnie z „wytycznymi konwencji CITES w sprawie transportu i przygotowania do przewozu żywych dzikich zwierząt i żywych roślin".

Konwencja CITES ${ }^{25}$, a także implementujące ją do porządku prawnego UE Rozporządzenie Rady (WE) nr 338/97 z dnia 9 grudnia 1996 r. w sprawie ochrony gatunków dzikiej fauny i flory w drodze regulacji handlu nimi oraz zmieniające je Rozporządzenie Komisji (WE) nr 1497/2003 przewidują natomiast, że „wszelkie żywe okazy przewożone do Wspólnoty, ze Wspólnoty lub w jej obrębie przechowywane w czasie jakiegokolwiek okresu tranzytu lub przeładunku mają być przygotowane, przenoszone i otoczone opieką w taki sposób, aby zmniejszyć ryzyko uszkodzenia, utraty zdrowia lub okrutnego traktowania"26.

Przewóz zwierząt na terenie UE podlega jednak przede wszystkim nadzorowi weterynaryjnemu. Zgodnie z Rozporządzeniem Komisji (WE) nr 599/2004 dotyczącym przyjęcia zharmonizowanego wzoru świadectwa i sprawozdania z kontroli związanych z wewnątrzwspólnotowym handlem zwierzętami i produktami pochodzenia zwierzęcego (dalej: Rozporządzenie Komisji (WE) nr 599/2004) ${ }^{27}$ zarówno eksport, import, jak i przewóz (tranzyt) przez terytorium państw członkowskich UE zwierząt i produktów z państw trzecich przeznaczonych na eksport do państw trzecich odbywa się poprzez rejestrację przesyłek w systemie TRACES ${ }^{28}$. Jest to unijny system kontroli i powiadamiania o przemieszczeniu zwierząt żywych oraz niektórych produktów pochodzenia zwierzęcego przez terytorium państw członkowskich $\mathrm{UE}^{29}$. Ma on zasadniczo trzy cele. Po pierwsze, na jego podstawie

25 Zob. art. III, pkt 2, ppkt c konwencji CITES. Pełny tekst konwencji dostępny jest na stronie CITES, https://www.cites.org/sites/default/files/eng/disc/CITES-Convention-EN.pdf [dostęp: 10.02.2020 r.].

26 Art. 9 pkt 2 ust. 5 Rozporządzenia Rady (WE) nr 338/97.

27 Rozporządzenie Komisji (WE) nr 599/2004 z dnia 30 marca 2004 r. dotyczące przyjęcia zharmonizowanego wzoru świadectwa i sprawozdania z kontroli związanych z wewnątrzwspólnotowym handlem zwierzętami i produktami pochodzenia zwierzęcego, Dz. Urz. UE L 94 z 31.3.2004, s. 44-56.

28 Kontrole weterynaryjne produktów z państw trzecich wprowadzanych na terytorium państw członkowskich odbywają się zgodnie z dyrektywą Rady 97/78/WE z dnia 18 grudnia 1997 r. ustanawiającą zasady regulujące organizację kontroli weterynaryjnej produktów wprowadzanych do Wspólnoty z państw trzecich, Dz. Urz. UE L 24 z 30.1.1998, s. 9-30.

29 Zob. decyzje Komisji (UE) wprowadzające system TRACES: Decyzja Komisji z dnia 30 grudnia 2002 r. dotycząca opracowania zintegrowanego skomputeryzowanego systemu weterynaryjnego (notyfikowana jako dokument nr C(2002) 5496) (2003/24/WE), Dz. Urz. UE L 008 z 14.1.2003, s. 44-45; Decyzja Komisji z dnia 19 sierpnia 2003 r. dotycząca opracowania zintegrowanego skomputeryzowanego systemu weterynaryjnego pod nazwą TRACES (notyfikowana jako dokument nr C(2003) 2983) (2003/623/WE), Dz. Urz. UE L 216 z 28.8.2003, s. 58-59; Decyzja Komisji z dnia 30 marca 2004 r. w sprawie wprowadzenia systemu TRACES i zmieniająca decyzję 92/486/EWG (notyfikowana jako dokument nr C(2004) 1282), Dz. Urz. UE L 094 z 31.3.2004, s. 63-64; Decyzja Komisji z dnia 30 marca 2004 r. w sprawie wprowadzenia systemu TRACES i zmieniająca decyzję 92/486/ 
wystawiane są świadectwa weterynaryjne dla żywych zwierząt i pewnych produktów pochodzenia zwierzęcego w handlu wewnątrzunijnym. Po drugie, na jego podstawie wystawiane są również dokumenty dla wwożonych na terytorium państw członkowskich UE zwierząt i produktów z państw trzecich. I w końcu po trzecie co miało największe znaczenie w odniesieniu do tygrysów będących przedmiotem niniejszego artykułu - tworzy on skomplikowany system nadzoru weterynaryjnego pomiędzy państwami UE.

Rozporządzenie Parlamentu Europejskiego i Rady(UE) 2017/625 z dnia 15 marca 2017 r. w sprawie kontroli urzędowych i innych czynności urzędowych przeprowadzanych w celu zapewnienia stosowania prawa żywnościowego i paszowego oraz zasad dotyczących zdrowia i dobrostanu zwierząt, zdrowia roślin i środków ochrony roślin ${ }^{30}$ natomiast (choć nie odnosi się bezpośrednio do zwierząt egzotycznych) przewiduje szczegółowy sposób kontroli granicznych dobrostanu przewożonych z/ do/przez kraje UE zwierząt ${ }^{31}$.

Brak jest aktów prawnych o krajowej genezie, które obejmują swoim zasięgiem transport zwierząt egzotycznych ${ }^{32}$. W polskim systemie prawnym bezpo-

EWG (notyfikowana jako dokument nr C(2004) 1282), Dz. Urz. UE L 94 z 31.3.2004, s. 63-64; Decyzja Komisji z dnia 28 września 2009 r. ustalająca wykaz zatwierdzonych punktów kontroli granicznej, ustanawiająca niektóre zasady kontroli przeprowadzanych przez ekspertów weterynaryjnych Komisji oraz ustanawiająca jednostki weterynaryjne w systemie TRACES (notyfikowana jako dokument nr C(2009) 7030); aktualnie obowiązująca Decyzja wykonawcza Komisji (UE) 2019/2001 z dnia 28 listopada 2019 r. zmieniająca decyzję 2009/821/WE w odniesieniu do wykazów punktów kontroli granicznej i jednostek weterynaryjnych w systemie TRACES (notyfikowana jako dokument nr C(2019) 8579), Dz. Urz. UE L 310 z 2.12.2019, s. 46-49.

30 Rozporządzenie 2017/625 z dnia 15 marca 2017 r. w sprawie kontroli urzędowych i innych czynności urzędowych przeprowadzanych w celu zapewnienia stosowania prawa żywnościowego i paszowego oraz zasad dotyczących zdrowia i dobrostanu zwierząt, zdrowia roślin i środków ochrony roślin, zmieniające rozporządzenia Parlamentu Europejskiego i Rady (WE) nr 999/2001, (WE) nr 396/2005, (WE) nr 1069/2009, (WE) nr 1107/2009, (UE) nr 1151/2012, (UE) nr 652/2014, (UE) 2016/429 i (UE) 2016/2031, rozporządzenia Rady (WE) nr 1/2005 i (WE) nr 1099/2009 oraz dyrektywy Rady 98/58/ WE, 1999/74/WE, 2007/43/WE, 2008/119/WE i 2008/120/WE, oraz uchylające rozporządzenia Parlamentu Europejskiego i Rady (WE) nr 854/2004 i (WE) nr 882/2004, dyrektywy Rady 89/608/ EWG, 89/662/EWG, 90/425/EWG, 91/496/EWG, 96/23/WE, 96/93/WE i 97/78/WE oraz decyzję Rady 92/438/EWG (rozporządzenie w sprawie kontroli urzędowych), Dz. Urz. UE L 95 z 7.4.2017, s. 1-142. Dyrektywa ta zastąpiła poprzednio obowiązującą, a wprowadzającą funkcjonowanie systemu TRACES do UE Dyrektywę Rady 97/78/WE z dnia 18 grudnia 1997 r. ustanawiającą zasady regulujące organizację kontroli weterynaryjnej produktów wprowadzanych do Wspólnoty z państw trzecich, Dz. Urz. UE L 24 z 30.1.1998, s. 9-30.

31 W odniesieniu do pojęcia dobrostanu zob. np. A. Elżanowski, Czym jest i nie jest dobrostan, w: Dobrostan zwierząt. Różne perspektywy, red. H. Mamzer, Gdańsk 2018, s. 51-70.

32 Warto wspomnieć, że ustawa z dnia 21 sierpnia 1997 r. o ochronie zwierząt (Dz. U. z 1997 r. Nr 111, poz. 724), będąca jednym $z$ bardziej podstawowych aktów prawnych w polskim systemie prawnym, nie dotyczy gatunków egzotycznych (a jedynie zwierząt żyjących dziko na terenie Rzeczypospolitej 
średnio do ich przewozu odnoszą się jedynie akty prawne dotyczące wymogów weterynaryjnych związanych $\mathrm{z}$ transportem tych zwierząt. Należą do nich: ustawa $\mathrm{z}$ dnia 27 sierpnia $2003 \mathrm{r}$. o weterynaryjnej kontroli granicznej ${ }^{33}$ oraz ustawa z dnia 11 marca 2004 r. o ochronie zdrowia zwierząt oraz zwalczaniu chorób zakaźnych zwierzą ${ }^{34}$.

\section{Prawidłowość stosowania regulacji prawnych systemu prawa UE przez organy państwowe krajów członkowskich w przypadku transportu tygrysów}

Biorąc pod uwagę, że w przypadku transportu tygrysów zwierzęta spędziły kilka dni, nie opuszczając klatek (mimo deklarowanego dopełnienia procedur unijnych), w pierwszej kolejności zbadać należy prawidłowość dostosowania procedur obowiązujących na polskich przejściach granicznych do wymogów określonych w aktach prawnych wydanych przez organy UE. Zgodnie z art. 36 ustawy o Inspekcji Weterynaryjnej ${ }^{35}$ organem odpowiedzialnym za dostosowanie polskiego porządku prawnego do wymogów zawartych w unijnych przepisach dotyczących transportu zwierząt jest Główny Lekarz Weterynarii. Dokumentem istotnym dla oceny analizowanego stanu faktycznego jest oświadczenie Prezesa Krajowej Izby Lekarsko-Weterynaryjnej wydane w związku z zarzutem niedopełnienia obowiązków służbowych przez granicznego lekarza weterynarii na przejściu w Koroszczynie ${ }^{36}$. Zgodnie zgodnie z treścią oświadczenia Prezesa Krajowej Izby Lekarsko-Weterynaryjnej, graniczni lekarze weterynarii „nie przeprowadzają weterynaryjnej kontroli granicznej zwierząt opuszczających Unię Europejską", a przedmiotem ich kontroli

Polskiej). Zob. też E. Ząbek, N. Kulbacka, International and National Legal Standards for the Protection of Wild Animals, w: Legal protection of Animals, red. E. Kruk, G. Lubeńczuk, H. Spasowska-Czarny, Lublin 2020, w której autorzy odnoszą się także do transportu dziko żyjących zwierząt, np. s. 151.

33 Ustawa z dnia 27 sierpnia 2003 r. o weterynaryjnej kontroli granicznej, Dz. U. z 2003 r. Nr 165, poz. 1590.

34 Ustawa z dnia 11 marca 2004 r. o ochronie zdrowia zwierząt oraz zwalczaniu chorób zakaźnych zwierząt, Dz. U. z 2004 Nr 69, poz. 625.

35 Ustawa z dnia 29 stycznia 2004 r. o Inspekcji Weterynaryjnej, Dz. U. z 2004 r. Nr 33, poz. 287 (tekst jednolity: Dz. U. z 2018 r. poz. 1557, z 2020 r. poz. 285).

36 Weterynarz usłyszał bowiem zarzuty niedopełnienia obowiązków i został zawieszony w czynnościach służbowych. Tak właśnie: K. Kot, Są zarzuty dla lekarza weterynarii. Chodzi o transport tygrysów, RMF24, 25.11.2019 r., https://www.rmf24.pl/fakty/polska/news-sa-zarzuty-dla-lekarza-weterynarii-chodzi-o-transport-tygrys,nId,3354030 [dostęp: 10.02.2020 r.]. 
jest jedynie sprawdzenie „czy transport opuszczający Unię Europejską jest zgodny $z$ informacją w informatycznym systemie TRACES" ${ }^{37}$.

Weryfikacja legalności działań granicznych lekarzy weterynarii w przedstawianym przypadku jest zagadnieniem złożonym ${ }^{38}$. Ustawa o weterynaryjnej kontroli granicznej określa bowiem jedynie wymóg weterynaryjnej kontroli granicznej przesyłek zwierząt wprowadzanych do UE z państw trzecich ${ }^{39}$. W doktrynie brakuje głosów, na podstawie których można byłoby dokonywać szerszej interpretacji przepisów tejże ustawy. Brak również dorobku orzeczniczego dotyczącego kontroli dokonywanych w przypadku przewożenia żywych zwierząt wewnątrz UE.

Treść oświadczenia Prezesa Krajowej Izby Lekarsko-Weterynaryjnej nie odzwierciedla jednak założeń Rozporządzenia 2017/625 z dnia 15 marca 2017 r. w sprawie kontroli urzędowych. Zgodnie z przepisami tego rozporządzenia „kontrole powinny odbywać się z częstotliwością zależną od ryzyka stwarzanego przez każde zwierzę" - zarówno dla zdrowia ludzi, jak i dla dobrostanu zwierzą ${ }^{40}$. Założenie dotyczące częstotliwości kontroli dotyczy zarówno kontroli identyfikacyjnych, jak i bezpośrednich (które w przypadku transportu przedmiotowych tygrysów powinny objąć kontrolę opakowania, w którym się znajdywały, środków transportu, oznakowania i temperatury $)^{41}$. Co więcej, przepisy tego rozporządzenia określają wyraźnie, że takie same kontrole powinny obejmować zwierzęta wywożone $z \mathrm{UE}^{42}$, a więc także tygrysy, do których odnosi się niniejsze opracowanie. Zgodnie z dokonywaną przeze mnie interpretacją przepisów Rozporządzenia 2017/625 z dnia 15 marca 2017 r. w sprawie kontroli urzędowych stan przewożonych tygrysów i bezpieczeństwa opakowań, w których się znajdowały, powinien - ze względu na stwarzane przez zwierzęta ryzyko - zostać skontrolowany już podczas ich wjazdu na teren Polski ${ }^{43}$, a dodatkowo przy opuszczaniu granic naszego kraju ${ }^{44}$.

Przepisy ustawy o weterynaryjnej kontroli granicznej nie uwzględniają zatem wymogów stawianych osobom odpowiedzialnym w danym kraju za kontrolę przewożonych w UE zwierząt na podstawie Rozporządzenia Parlamentu Europejskiego i Rady (UE) 2017/625 z dnia 15 marca 2017 r. w sprawie kontroli urzędowych.

\footnotetext{
37 Wspólne Oświadczenie...

38 Zob. pkt. 3 powyżej, a także m.in. E. Łętowska, Multicentryczność współczesnego systemu prawa $i$ wykładnia jej przyjazna..., s. 1127; A. Kalisz, Multicentryczność systemu prawa polskiego..., s. 35.

39 Art. 4 pkt. 1 ustawy o weterynaryjnej kontroli granicznej.

$40 \quad$ Art. 54 pkt. 2 Rozporządzenia 2017/625.

41 Zob. definicję art. „kontroli identyfikacyjnej” i „kontroli bezpośredniej” w art. 2 Rozporządzenia $2017 / 625$.

42 Por. Art. 1 pkt. 3 oraz art. 9 pkt. 6 b) Rozporządzenia 2017/625.

43 Art. 54 pkt. 2 Rozporządzenia 2017/625.

44 Art. 1 pkt. 3 oraz art. 9 pkt. 6 b) Rozporządzenia 2017/625.
} 
Podczas gdy pracownicy Krajowej Izby Lekarsko-Weterynaryjnej i Inspekcji Weterynaryjnej „apelują do decydentów o podjęcie systemowych działań legislacyjnych i organizacyjnych, aby takie sytuacje już więcej się nie powtarzały" ${ }^{45}$, należy mieć na uwadze, że „żadne państwo nie może powoływać się na prawo wewnętrzne, by usprawiedliwić niewywiązywanie się ze zobowiązań międzynarodowych" ${ }^{46}$. Nie należy zatem obarczać organów wyższego szczebla niestosowaniem wymogów odnoszących się do transportu tygrysów w prawie UE przez władze krajowe a przyjąć odpowiedzialność za nieprawidłowe stosowanie prawa przez polskiego Głównego Lekarza Weterynarii.

Kolejnym elementem składowym w analizowanym kontekście, który doprowadził do stanu zagrażającego życiu tygrysów, a także spowodował utratę życia przez jednego z nich, był „brak możliwości poprawy ich warunków dobrostanu w podróży poprzez wypuszczenie np. do większych klatek" na przejściu w Koroszczynie ${ }^{47}$ i pozostawienie ich $\mathrm{w}$ ciężarówce przez cały okres transportu ${ }^{48}$. Tygrysy przebywały $\mathrm{w}$ nieodpowiednich kontenerach nie tylko podczas przejazdu przez kraje UE, ale także po tym, kiedy uniemożliwiony został wjazd transportu na teren Białorusi. Punkty kontroli granicznej przeznaczone dla przewozu zwierząt powinny bowiem mieć specjalną drogę dostępu lub inne rozwiązania w celu ich zabezpieczenia „przed niepotrzebnym czekaniem przed dotarciem do strefy rozładunku”"49. W przypadku niebezpiecznych i egzotycznych zwierząt, których transport odbywa się stosunkowo rzadko, a ich rozładunek zagraża zdrowiu i życiu ludzi, odpowiednim rozwiązaniem jest opracowanie awaryjnych proceadur polegających na natychmiastowym przewożeniu tego rodzaju zwierząt do najbliżej położonego ogrodu zoologicznego. W analizowanym stanie faktycznym takich procedur zabrakło ${ }^{50}$. Organem

$45 \quad$ Wspólne Oświadczenie...

46 W. Czapliński, Unia nie jest potworem, w: Implementacja prawa integracji europejskiej $w$ krajowych porząkach prawnych, red. C. Mika, Toruń 1998.

47 R. Maślankiewicz, Tygrysy i dostęp do informacji publicznej, Sieć obywatelska, 11.12.2019, https://siecobywatelska.pl/tygrysy-i-dostep-do-informacji-publicznej/ (strona internetowa odwiedzona po raz ostatni w dniu 10 lutego 2020 r.). Informacje te potwierdzone zostały także w Oświadczeniu Prezesa Krajowej Izby Lekarsko-Weterynaryjnej i Przewodniczącej Ogólnopolskiego Związku Zawodowego Pracowników Inspekcji Weterynaryjnej z dnia 2 grudnia 2019 r.

48 Por. obowiązki związane z transportem zwierząt w opisie J. Miłkowskiej-Rębowskiej, J. Miłkowska-Rębowska, w: M. Górski, Prawo ochrony środowiska, Warszawa 2018, s. 785.

49 Zob. procedury przewidziane w art. 5 pkt. 1 g) Rozporządzenia wykonawczego Komisji (UE) 2019/1014 z dnia 12 czerwca 2019 r. ustanawiającego szczegółowe przepisy w zakresie minimalnych wymogów dotyczących punktów kontroli granicznej, w tym ośrodków inspekcyjnych, oraz formatu, kategorii i skrótów stosowanych w wykazach punktów kontroli granicznej i punktów kontroli. Zob. także art. 21 Rozporządzenia 2017/625.

50 Zob. struktura organów Inspekcji Weterynaryjnej w Polsce, zob. art. 6 ustawy o inspekcji weterynaryjnej. Zgodnie z ustawą Główny Lekarz Weterynarii podlega ministrowi właściwemu do spraw 
odpowiedzialnym za wydawanie instrukcji określających sposób postępowania $\mathrm{w}$ ramach przeprowadzanych kontroli, $\mathrm{w}$ tym instrukcji dotyczących stosowania przez organy Inspekcji przepisów UE, jest Główny Lekarz Weterynariii ${ }^{51}$. Zgodnie z ustawą o Inspekcji Weterynaryjnej Prezes Rady Ministrów może wyciągnąć konsekwencje w związku z nieprawidłowym wykonywaniem zadań przez Głównego Lekarza Weterynarii, włącznie z możliwością odwołania go ze stanowiska ${ }^{52}$. Główny Lekarz Weterynarii twierdzi jednak, że polskie służby weterynaryjne i celne należycie wywiązały się ze swoich zadań ${ }^{53} \mathrm{i}$ brak jest informacji o poniesionych przez niego jakichkolwiek konsekwencjach.

Obok okoliczności mogących wskazywać zaniedbania ze strony polskich organów administracji najistotniejszym czynnikiem składającym się na doprowadzenie przedmiotowych tygrysów do stanu zagrożenia lub utraty życia jest wprowadzenie przez organy administracyjne do systemu TRACES dokumentów przedstawiających wymagane w UE świadectwo weterynaryjne INTRA i trasy zaplanowanej dla ciężarówki wiozącej tygrysy bez zwrócenia uwagi na brak spełnienia wymogów państwa docelowego, znajdującego się poza terenem UE. Organ administracyjny państwa członkowskiego, w którym dane zwierzę się znajduje, wydaje bowiem zezwolenie na przewóz w obrębie UE żywych okazów gatunków wymienionych w załączniku A do Rozporządzenia Rady (WE) nr 338/97, a właściwe organy państw członkowskich mają za zadanie jedynie monitorować przestrzeganie przepisów tego rozporządzenia ${ }^{54}$.

Z uwagi na to, że tygrysy należą do załącznika A do Rozporządzenia Rady (WE) nr 338/9755 (zgodnie z Rozporządzeniem Komisji (WE) nr 1497/2003), zezwolenie na ich wywóz może być wydane tylko przy uwzględnieniu szeregu ograniczeń i spełnieniu restrykcyjnych wymagań związanych z przysługującą im ochroną gatunkową. Dlatego też organ administracyjny na terenie Włoch powinien był

rolnictwa i powoływany jest przez Prezesa Rady Ministrów na wniosek ministra właściwego do spraw rolnictwa. Prezes Rady Ministrów odwołuje Głównego Lekarza Weterynarii. Poza Głównym Lekarzem Weterynarii organami Inspekcji Weterynaryjnej są: wojewódzki lekarz weterynarii, powiatowy lekarz weterynarii oraz graniczny lekarz weterynarii.

51 Por. art. 13 pkt 1 i 2 ustawy o inspekcji weterynaryjnej oraz art. 4 pkt 1 i art. 10 pkt 1 a) Rozporządzenia $2017 / 625$.

52 Zob. art. 6 ustawy o inspekcji weterynaryjnej.

53 „Główny Lekarz Weterynarii: ws. tygrysów: Polskie służby weterynaryjne wywiązały się z zadań. Lekarz graniczny otrzymat nagrodę, Dziennik GazetaPrawna.pl, 6.11.2019, https://www.gazetaprawna.pl/artykuly/1438460,glowny-lekarz-weterynarii-ws-tygrysow-polskie-sluzby-weterynaryjne -wywiazaly-sie-z-zadan-lekarz-graniczny-otrzymal-nagrode.html [dostęp: 10.02 .2020 r.].

54 Zobacz: art. 5 ust. 1; art. 9 ust. 1; art. 13 ust. 1, a); art. 14 ust. 1, a); art. 16 ust. 1 Rozporządzenia Rady (WE) nr 338/97.

55 Por. art. 41 ustawy o weterynaryjnej kontroli granicznej. 
upewnić się, że zwierzęta te zostały przygotowane i przesłane w taki sposób, aby zmniejszyć ryzyko uszkodzenia, utraty zdrowia lub okrutnego traktowania, a także, iż nie będą one wykorzystywane do celów głównie handlowych, oraz - po konsultacjach z właściwym organem naukowym - że z ochroną gatunku nie wiążą się żadne inne czynniki, które przemawiają przeciwko wydaniu zezwolenia na wywóz ${ }^{56}$. Wymogi te nie zostały dochowane.

Po pierwsze, organy administracyjne na terenie Włoch wydały zgodę na transport tygrysów w nieodpowiednich kontenerach ${ }^{57}$. Po drugie, nie zostały one prawidłowo oznakowane. Po trzecie, zwierzęta te przewożone były bez odpowiednich dokumentów (tj. takich, które wymagane są w kraju przeznaczenia, a nie w kraju wywozu). Dlatego też odpowiednie organy na terenie Włoch ponoszą odpowiedzialność za wyrażenie zgody na transport zwierząt bez dokumentów wymaganych w kraju docelowym i w nieodpowiednich warunkach ${ }^{58}$. Po dostrzeżeniu uchybień ze strony włoskiej, zgodnie z przepisami ustawy o weterynaryjnej kontroli granicznej, polski Główny Lekarz Weterynarii powinien o zaistniałych uchybieniach poinformować włoskie organy kontroli granicznej ${ }^{59}$, a także Komisję Europejską ${ }^{60}$.

\section{Jak uniknąć śmierci dzikich zwierząt przewożonych na terenie UE w przyszłości? Wnioski}

Przedstawiony w opracowaniu przypadek wskazuje na trzy podstawowe zagrożenia dobrostanu dzikich zwierząt podczas transportu z/do/przez kraje UE.

56 Art. 5 pkt 2 a) Rozporządzenia Rady (WE) nr 338/97.

57 Poza wymogami przewidzianymi w przedstawionych w zdaniu wcześniej aktach prawnych (Rozporządzenie Rady (WE) nr 338/97, Rozporządzenie 1497/2003), wymogi dotyczące odpowiedniego dostosowania klatek, w których znajdowały się tygrysy w czasie transportu przewidziane w CITES, także nie zostały dochowane, zob. art. 43 konwencji CITES.

58 Zob. art. 4 pkt 1 Rozporządzenia 2017/625, zgodnie z którym to państwa członkowskie wyznaczają właściwy organ lub właściwe organy, na które nakładają obowiązek organizowania lub przeprowadzania kontroli urzędowych przewożonych zwierząt. Zob. także sankcje przewidziane w przypadku, gdy Komisja Europejska posiada dowody na wystąpienie poważnego zakłócenia w systemie kontroli państwa członkowskiego, które może pociągać za sobą powszechne ryzyko dla zdrowia ludzi, zwierząt lub roślin, dobrostanu zwierząt w art. 141 Rozporządzenia 2017/625.

59 Zob. art. 41.1. ustawy o weterynaryjnej kontroli granicznej. Por. preambuła oraz art. 1 Rozporządzenia 2017/625.

60 Art. 140 Rozporządzenia 2017/625. 
Po pierwsze, brak jest odgórnego systemu kontroli na poziomie UE ${ }^{61}$. W konsekwencji:

1) przejścia graniczne nie są dostosowane do wymogów prawnych mających zapewnić dobrostan zwierząt podczas przewozów międzynarodowych (np. poprzez konieczność zapewnienia rozładunku zwierząt w przypadku niemożliwości ich dotarcia do punktu docelowego w zaplanowanym wcześniej czasie);

2) właściwe organy powołane w tym celu przez poszczególne państwa członkowskie nie są rozliczane $\mathrm{z}$ wdrażania $\mathrm{w}$ tychże krajach procedur wynikających z aktów prawnych wydawanych przez organy UE - jest to główny powód, dla którego przedstawione w punkcie 3. organy państw Włoch i Polski nie zostały pociągnięte do odpowiedzialności w związku z niewypełnianiem obowiązków ${ }^{62}$;

3) osoby zajmujące się zawodowo przewozem zwierząt nie mają podstawowej wiedzy w zakresie opieki i postępowania z dzikimi zwierzętami (np. ich karmienia, co było widoczne w przedstawianym przypadku), zwierzętami, których przewóz stanowi zagrożenia dla życia i zdrowia ludzkiego, jak również na temat zagrożonych gatunków zwierząt (o ile szkolenia takie odbywają się w odniesieniu do przewozu zwierząt hodowlanych, brak informacji na temat szkoleń obejmujących zakres tematyczny przewozu zwierząt egzotycznych) ${ }^{63}$ - przyczyna zgonu jednego z tygrysów wskazuje właśnie na braki w szkoleniu osób przewożących zwierzęta.

Po drugie, uwidocznione zostały wady funkcjonowania systemu TRACES. Jako zaawansowany system informatyczny powinien on bowiem uniemożliwiać zarejestrowanie transportu zwierząt bez załączenia w formie cyfrowej dokumentów wymaganych do okazania w punkcie kontroli granicznej w kraju trzecim. Dodatkowo,

61 Do tej pory najbardziej efektywnym aktem prawnym podpisanym przez wszystkie państwa w UE jest CITES. Niestety, sama konwencja nie przewiduje sankcji za nieprzestrzeganie jej postanowień, odpowiedzialne są za to same państwa członkowskie. Choć Komisja Europejska bada stopień wdrożenia CITES w krajach członkowskich, rola ta ogranicza się jedynie do wydawania raportów i zaleceń. Aby móc realnie wpływać na efektywność wdrażania przepisów konwencji i egzekwowania sankcji za ich nieprzestrzeganie, konieczne byłoby powołanie odpowiedniego organu do spraw ochrony praw zwierząt na poziomie UE.

62 Warto zwrócić uwagę na publikację, która - choć odnosi się przede wszystkim do zwierząt hodowlanych - stanowi bardzo ważny wkład w rozwój doktryny i podkreśla znaczenie odpowiedniego monitorowania przepisów pod kątem ich przestrzegania w UE, zob. V.A. Cussen, Enforcement of Transport Regulations: the EU as Case Study, w: Long Distance Transport and Welfare of Farm Animals, red. M.C. Appleby, V. Cussen, L. Garces, L.A. Lambert, J. Turner, Wallingford 2008, s. 113.

63 Zob. opis wymogów dotyczących szkoleń przewoźników zwierząt zgodnie z Załącznikiem IV do Rozporządzenie Rady (WE) nr 1/2005. Niestety, rozporządzenie to nie odnosi się do zwierząt egzotycznych, dlatego też nie sposób spodziewać się szkolenia w tematyce obchodzenia się z tego rodzaju zwierzętami. 
ze względu na integralność Europy, w systemie elektronicznym obsługującym przewozy międzynarodowe konieczne jest uwzględnienie także krajów znajdujących się poza UE.

Po trzecie - w odniesieniu do przewozu zwierząt z/do/przez kraje członkowskie UE - dużą trudność sprawia wskazanie norm prawnych dotyczących zwierząt egzotycznych na poziomie ponadnarodowym. Zasadniczym aktem prawnym, mającym na celu ochronę tego rodzaju zwierząt, jest konwencja CITES. Stanowi ona jednak jedynie ogólną regulację prawną, nie obejmując swym zakresem rozwiązań technicznych, funkcjonalnych $\mathrm{w}$ przypadkach podobnych do przedstawionego. Choć odpowiednie regulacje $\mathrm{w}$ tym zakresie powinno zapewnić ustawodawstwo na poziomie UE, przedstawiona $\mathrm{w}$ tym opracowaniu analiza przypadku przewozu tygrysów wskazuje na potencjalne występowanie licznych luk prawnych w tym zakresie. Przede wszystkim Rozporządzenie Rady (WE) nr 1/2005 nie odnosi się do zwierząt egzotycznych. W tej sytuacji jedynymi przepisami regulującymi tego rodzaju transport zwierząt są te odnoszące się do wymogów weterynaryjnych oraz przepisy mające na celu wdrożenie elektronicznego systemu TRACES. Uważam, że organy UE powinny znowelizować Rozporządzenie Rady (WE) nr 1/2005 poprzez dodanie kolejnego rozdziału odnoszącego się do procedur związanych z transportem zwierząt egzotycznych, objętych ochroną na podstawie konwencji CITES. Dołączenie tego rodzaju przepisów do Rozporządzenia Rady (WE) nr 1/2005 wpłynęłoby także w mojej ocenie pozytywnie na przejrzystość przepisów prawa unijnego dotyczących zwierząt dziko żyjących (w tym egzotycznych) poprzez bezpośrednie odniesienie się do konwencji CITES.

W analizowanym przypadku nie występuje jednak luka prawna, doszło jedynie do błędnej interpretacji, a następnie błędnego stosowania prawa UE przez organy państwowe Włoch i Polski. Wskazane jest jednakże znowelizowanie przepisów dotyczących transportu zwierząt egzotycznych na poziomie UE poprzez stworzenie bardziej efektywnego systemu kontroli oraz bezpośrednie odniesienie się do przepisów CITES w Rozporządzeniu Rady (WE) nr 1/2005.

Nawiązując do słów E. Łętowskiej, które wpisują się w analizowaną problematykę, antidotum na zasygnalizowane błędy w interpretacji i stosowaniu prawa jest zapewnienie efektywnego współistnienia obu porządków prawnych - polskiego krajowego systemu prawa, jak i systemu prawa UE (który powinien być spójny z polskim krajowym systemem prawnym, ale nawet w przypadku braku spójności - wciąż jest prawem obowiązującym) ${ }^{64}$. Jeśli chodzi o zapewnienie skuteczności stosowania prawa UE (effet utile), organy rangi państwowej (w analizowanym

E. Łętowska, Multicentryczność współczesnego systemu prawa i wykładnia jej przyjazna..., s. 1127. 
przypadku - Prezes Rady Ministrów) powinny wyciągać konsekwencje wobec funkcjonariuszy w razie niestosowania (bądź błędnego stosowania) przez nich aktów prawnych na poziomie prawa unijnego. I w końcu niezbędne jest - na poziomie prawa polskiego - wydanie przez Głównego Lekarza Weterynarii odpowiednich instrukcji dotyczących stosowania przepisów UE (które mogłyby się odnosić do sytuacji podobnych przedstawionej w tym opracowaniu) przez organy Inspekcji.

\section{Bibliografia}

Animal legislations in the world at national level, https://www.globalanimallaw.org/database/ national/index.html [dostęp: 10.02.2020 r.].

Cussen V.A., Enforcement of Transport Regulations: the EU as Case Study, w: Long Distance Transport and Welfare of Farm Animals, red. M.C. Appleby, V. Cussen, L. Garcés, L.A. Lambert, J. Turner, Wallingford 2008.

Czapliński W., Unia nie jest potworem, w: Implementacja prawa integracji europejskiej w krajowych porzadkach prawnych, red. C. Mika, Toruń 1998.

Dendera-Gruszka M., Masłowski D., Kulińska E., Maras D., Uwarunkowania prawne dotyczące pojazdów wykorzystywanych do przewozu zwierząt, w: Innowacje w zarzadzaniu i inżynierii produkcji, t. 1, red. R. Knosala, Opole 2018.

Elżanowski A., Czym jest i nie jest dobrostan, w: Dobrostan zwierzat. Różne perspektywy, red. H. Mamzer, Gdańsk 2018.

Główny Lekarz Weterynarii ws. tygrysów: Polskie stużby weterynaryjne wywiazaly się z zadań. Lekarz graniczny otrzymał nagrodę, Dziennik GazetaPrawna.pl, 6.11.2019, https:// www.gazetaprawna.pl/artykuly/1438460,glowny-lekarz-weterynarii-ws-tygrysow-polskie-sluzby-weterynaryjne-wywiazaly-sie-z-zadan-lekarz-graniczny-otrzymal-nagrode.html [dostęp: 10.02.2020 r.].

Górski M., Prawo ochrony środowiska, Warszawa 2018.

Hantz K., Żukowska K., Grieger A., Wymagania stawiane środkom transportu przy przewozie zwierzat żywych, Autobusy 2016, nr 8, s. 236-239.

Klat-Wertelecka L., Zasada pierwszeństwa prawa unijnego w działaniu organów administracji publicznej, w: Zasada pierwszeństwa prawa Unii Europejskiej w praktyce działania organów władzy publicznej RP, red. M. Jabłoński, S. Jarosz-Żukowska, Wrocław 2015.

Kalisz A., Multicentryczność systemu prawa polskiego a działalność orzecznicza Europejskiego Trybunału Sprawiedliwości i Europejskiego Trybunału Praw Człowieka, Ruch Prawniczy, Ekonomiczny i Socjologiczny 2007, z. 4, s. 35.

Kot K., Sa zarzuty dla lekarza weterynarii. Chodzi o transport tygrysów, RMF24, 25.11.2019 r., https://www.rmf24.pl/fakty/polska/news-sa-zarzuty-dla-lekarza-weterynarii-chodzi-o-transport-tygrys,nId,3354030 [dostęp: 10.02.2020 r.].

Krämer L., EU Environmental Law, London 2016. 
Król M. A., Humanitarna ochrona zwierząt, w: Prawa i obowiązki przedsiębiorców w ochronie środowiska. Zarys encyklopedyczny, red. P. Korzeniowski, Warszawa 2010.

Kupczyński R., Transport zwierząt - o czym trzeba pamiętać?, agroFakt24, https://www.agrofakt.pl/transport-zwierzat/ [dostęp: 9.03.2021 r.].

Kustra A., Polemika. Wokół multicentryczności systemu prawa, Państwo i Prawo 2006, z. 6.

Łętowska E., Multicentryczność współczesnego systemu prawa i wykładnia jej przyjazna, w: Rozprawy prawnicze. Ksiegga pamiątkowa profesora Maksymiliana Pazdana, red. L. Ogiegło, W. Popiołek, M. Szpunar, Kraków 2002.

Łętowska E., Multicentryczność współczesnego systemu prawa i jej konsekwencje, Państwo i Prawo 2005, z. 4.

Maślankiewicz R., Tygrysy i dostęp do informacji publicznej, Sieć obywatelska, 11.12.2019, https:// siecobywatelska.pl/tygrysy-i-dostep-do-informacji-publicznej/ [dostęp: 10.02.2020 r.].

Pietrzykowski T., Naturalizm i granice nauk prawnych. Esej z metodologii prawoznawstwa, Warszawa 2017.

Rott-Pietrzyk E., w: System Prawa Prywatnego, t. 20A. Prawo prywatne międzynarodowe, red. M. Pazdan, Warszawa 2014.

Szczepańska A., Wymogi dotyczące środków transportowych przy przewozie zwierząt żywych, Logistyka 2012, nr 3.

Sprawozdanie Komisji dla Parlamentu Europejskiego i Rady w sprawie wpływu rozporządzenia Rady (WE) nr 1/2005 w sprawie ochrony zwierząt podczas transportu, Bruksela, dnia 10.11.2011, KOM(2011) 700 wersja ostateczna.

TVN24 (Autor: js//now,FC/gp), Udało nam się uratować dziewięć istnień tygrysich. Jeden jest w ciężkim stanie, https://tvn24.pl/polska/tygrysy-z-granicy-z-bialorusia-trafily-do-zoo-w-poznaniu-i-czluchowie-ra981836-2307337 [dostęp: 10.02.2020 r.].

Wspólne Oświadczenie Prezesa Krajowej Izby Lekarsko-Weterynaryjnej i Przewodniczącej Ogólnopolskiego Związku Zawodowego Pracowników Inspekcji Weterynaryjnej z dnia 2.12.2019 r., https://www.vetpol.org.pl/images/pismarozne/WSPÓLNE_OŚWIADCZENIE_KILW_OZZPIW.pdf [dostęp:10.02.2020 r.].

Ząbek E., Kulbacka N., International and National Legal Standards for the Protection of Wild Animals, w: Legal protection of animals, red. E. Kruk, G. Lubeńczuk, H. Spasowska-Czarny, Lublin 2020.

Ziembiński Z., Metodologiczne zagadanienia prawoznawstwa, Warszawa 1974. 